\title{
Potentially toxic metal(loid) distribution and migration in the bottom weathering profile of indigenous zinc smelting slag pile in clastic rock region
}

\author{
Yishu Peng ${ }^{1}$, Ruidong Yang ${ }^{\text {Corresp., }}{ }^{2}$, Tao Jin ${ }^{3}$, Jun Chen ${ }^{4}$, Jian Zhang ${ }^{5}$ \\ ${ }^{1}$ College of Tea Science, Guizhou University, Guiyang, China \\ 2 \\ 2 College of Resources and Environmental Engineering, Guizhou University, Guiyang, China \\ 3 Institute of Mountain Resources of Guizhou Province, Guizhou Academy of Sciences, Guiyang, China \\ 4 State Key Laboratory of Ore Deposit Geochemistry, Institute of Geochemistry, Chinese Academy of Sciences, Guiyang, China \\ 5 College of Environmental Science and Engineering, Yangzhou University, Yangzhou, China \\ Corresponding Author: Ruidong Yang \\ Email address: rdyang@gzu.edu.cn
}

Background. There are contaminated by potentially toxic metal(loid)s (PTMs) that the surface soil and the weathering profiles around the indigenous zinc smelting slag piles or smelters in the smelting area. However, few systematic studies are currently focusing on the PTM distribution and migration among the slag and its bottom weathering profile.

Methods. This research determined the concentrations of PTMs and pH values. And we analyzed PTM distribution in the two weathering profiles (slag-covered and slag-absent) with a small horizontal distance in the clastic rock region in the smelting area.

Results. The soil As and $\mathrm{Pb}$ contents respective within the 30 -centimeter and $50 \mathrm{~cm}$ depth in the slagcovered section are higher than those in the slag-absent profile. And all soil $\mathrm{Cd}$ and $\mathrm{Zn}$ contents of the slag-covered core are significantly higher than those in the slag-absent weathering section.

Conclusions. Compared with the slag-absent weathering section, some PTMs (i.e., As, Cd, Pb, and Zn) in the bottom weathering profile are polluted by these elements in the covered slag in the clastic rock region. And their depths are influenced by the slag to varying degrees. Additionally, with time, some PTMs (especially $\mathrm{Cd}$ and $\mathrm{Zn}$ ) of the slag might finally contaminate the groundwater by leaching and infiltration through its bottom weathering profile in the clastic rock region. 
2 Potentially toxic metal(loid) distribution and migration

3 in the bottom weathering profile of indigenous zinc

4 smelting slag pile in clastic rock region

5

6

Yishu Peng ${ }^{1}$, Ruidong Yang 2 , Tao Jin ${ }^{3}$, Jun Chen ${ }^{4}$, Zhang Jian ${ }^{5}$

${ }^{1}$ College of Tea Science, Guizhou University, Guiyang 50025, China

${ }^{2}$ College of Resources and Environmental Engineering, Guizhou University, Guiyang 550025, China

${ }^{3}$ Institute of Mountain Resources of Guizhou Province, Guizhou Academy of Sciences, Guiyang 550001, China

${ }^{4}$ State Key Laboratory of Ore Deposit Geochemistry, Institute of Geochemistry, Chinese Academy of Sciences, Guiyang 550002, China

${ }^{5}$ College of Environmental Science and Engineering, Yangzhou University, Yangzhou 225127, China

Corresponding Author:

Ruidong Yang ${ }^{1}$

Graduate School of Guizhou University, Huaxi District, Guiyang 550025, Guizhou Province, PR China

Email address: rdyang@gzu.edu.cn

\section{Abstract}

Background. There are contaminated by potentially toxic metal(loid)s (PTMs) that the surface soil and the weathering profiles around the indigenous zinc smelting slag piles or smelters in the smelting area. However, few systematic studies are currently focusing on the PTM distribution and migration among the slag and its bottom weathering profile.

Methods. This research determined the concentrations of PTMs and $\mathrm{pH}$ values. And we analyzed PTM distribution in the two weathering profiles (slag-covered and slag-absent) with a small horizontal distance in the clastic rock region in the smelting area.

Results. The soil As and $\mathrm{Pb}$ contents respective within the 30 -centimeter and $50 \mathrm{~cm}$ depth in the slag-covered section are higher than those in the slag-absent profile. And all soil $\mathrm{Cd}$ and $\mathrm{Zn}$ contents of the slag-covered core are significantly higher than those in the slag-absent weathering section.

Conclusions. Compared with the slag-absent weathering section, some PTMs (i.e., As, $\mathrm{Cd}, \mathrm{Pb}$, and $\mathrm{Zn}$ ) in the bottom weathering profile are polluted by these elements in the covered slag in the 
39 clastic rock region. And their depths are influenced by the slag to varying degrees. Additionally,

40 with time, some PTMs (especially $\mathrm{Cd}$ and $\mathrm{Zn}$ ) of the slag might finally contaminate the

41 groundwater by leaching and infiltration through its bottom weathering profile in the clastic rock

42 region.

43

44 Introduction

45 Northwestern Guizhou is a concentrated region of the indigenous zinc smelting actives in 46 Guizhou Province, with a long smelting history of more than 300 years (Wei et al., 2020; Yang 47 et al., 2009; Zhou et al., 2020). And there is still a vital and hot study on the contamination of 48 49 potentially toxic metal(loid)s (PTMs: i.e., arsenic (As), cadmium (Cd), chromium (Cr), copper

99
$(\mathrm{Cu})$, mercury $(\mathrm{Hg})$, lead $(\mathrm{Pb})$, and zinc $(\mathrm{Zn}))$ in this region. Because there might be contaminating the surrounding environment and even endanger the health of animals or human beings due to PTMs of indigenous zinc slag. Randomly stacked and untreated slag has resulted in severe environmental pollution and risks in the indigenous zinc smelting region (Peng et al., 2018a). Although indigenous zinc smelting active has been banned by the local government for more than ten years (Peng et al., 2018b), there cannot be neglected the PTM contamination of the slag to their surrounding environment. The smelting slag-contaminated soils could increase the PTMs access by crops and vegetables (Liu et al., 2018). And the smelting activities are the dominant contribution to the $\mathrm{Pb}$ contamination in the mean of tissues of the maize from the $\mathrm{Pb}$ Zn smelting area in southwest China (Wei et al., 2020). PTMs originated from smelter-originated wastes that are transferred into the soil, and then that might be finally caused to urgent health risks of the exposure of local residents (Zhou et al., 2020).

PTM contamination exists in the surface soil and soil profiles around the smelters or slag heaps in indigenous zinc smelting areas. Some researchers have investigated the surface soil surrounding the smelters or slag heaps (Verner et al., 1996; Ullrich et al., 1999; Bi et al., 2006; Yang et al., 2009; Li et al., 2015; Wang et al., 2015). They concluded that some PTMs were exceeded their risk-based screening values for the soil contamination of agricultural land (MEE and SAMR, 2018). Additionally, in indigenous zinc smelting areas, soil profiles exhibit pollution by PTMs (especially in the surface soil), and the depths to which these elements migrate downward are significantly different. The $\mathrm{Cd}$ and $\mathrm{Zn}$ contamination depths could reach 2 meters surrounding a $\mathrm{Pb}$ and $\mathrm{Zn}$ smelter in the north of France (Sterckeman et al., 2000). The $\mathrm{Cu}, \mathrm{Pb}$, 
71 Northwest China (Wang et al., 2015). With increasing soil depths, the decreasing trend of Cd in 72 the whole soil profile was unclear, and soil $\mathrm{Pb}$ and $\mathrm{Zn}$ contents decreased abruptly and 73 respectively reached regional background levels at depths of 30 and $50 \mathrm{~cm}$ in Hezhang County, 74 China ( $\mathrm{Bi}$ et al., 2006). The $\mathrm{Pb}, \mathrm{Zn}, \mathrm{Cu}, \mathrm{Cr}, \mathrm{As}, \mathrm{Cd}$, and $\mathrm{Hg}$ contents decreased to their 75 background levels at a depth of approximately $150 \mathrm{~cm}$ around a smelter (Liu et al., 2015). 76 Besides, comparing with the surface soil at depths ranging from 0 to $10 \mathrm{~cm}$, there are polluted 77 and enriched by $\mathrm{Pb}, \mathrm{Zn}$, and $\mathrm{As}$ of the subsoil (depths ranging from 40 to $50 \mathrm{~cm}$ ) of some 78 locations near the town of Bytom where is an area of $\mathrm{Pb} / \mathrm{Zn}$ mining and smelting in Upper 79 Silesia, Poland (Ullrich et al., 1999). So there are many reports on the PTMs distribution of soil 80 profiles, and most of them only focus on the soil profiles around the slag piles in indigenous zinc 81 smelting areas (Scokart et al., 1983; Ullrich et al., 1999; Bi et al., 2006; Wang et al., 2015; Liu et 82 al., 2015). But few studies are currently focusing on PTMs distribution and migration in the 83 bottom weathering profile of the slag.

Additionally, to better understand the PTMs pollution in the bottom weathering profile 85 caused by indigenous zinc smelting slag, it is necessary to take the control profile. A diagnosis of 86 element soil pollution requires its pedogeochemical background content (Sterckeman et al.,

87 88 89 90 91 92 93 2000). The pedogeochemical background content generally means the corresponding horizons of noncontaminated and same type soils (Baize, 1994; Sterckeman et al., 2000). Under the condition of no contamination, the contents of elements in the soil and soil profile depend on the composition of the parent material and the degree of soil formation (Zhou et al., 2002). There are differences in parent materials formed by natural weathering with different bedrock (Yang et al., 2011; Peng et al., 2014).

Therefore, to better understand their contamination, distribution and migration of the soil section, we investigated the PTMs in the two weathering profiles (slag-covered and slag-absent) in the clastic rock region (where is one of the main stacking areas of the indigenous zinc smelting slag). Thus, there could help us better understand their PTMs contamination and provide some reasonable suggestions for better treating contamination of PTMs in the bottom weathering profile of the slag in the clastic rock.

\section{Materials \& Methods}

2.1 Soil profile sampling 
102

103

104

105

106

107

108

109

110

111

112

113

114

115

116

117

118

119

120

121

122

123

124

125

126

127

128

129

130

131

132

In August 2016, we collected 22 samples (approximately $1 \mathrm{~kg}$ each sample) from two weathering profiles (slag-covered and slag-absent) in an indigenous zinc smelting area in Honghualing of Dongfeng Town in Weining County, northwestern Guizhou Province, China. The soil is sandy loam weathered from the clastic rock. And the two weathering profiles had the same type of bedrock-weathered soil and were close to each other, which indicates that the two weathering profiles were under the same climatic and environmental conditions. So, their physical and chemical properties are similar.

As shown in Table S1, there were collected from the slag-covered weathering profile that a total of 12 samples (one slag sample and 11 soil samples). Ten soil samples from a slag-absent soil profile, which was well covered by natural vegetation and not covered by slag, approximately $100 \mathrm{~m}$ away from the slag-covered section, were collected. Except that two upper soil sampling thicknesses of two weathering profiles (slag-covered and slag-absent) were several $10 \mathrm{~cm}$ and $20 \mathrm{~cm}$, other soil sampling thicknesses of two sections were respective $20 \mathrm{~cm}$ and 25 $\mathrm{cm}$ until the dark gray sandy soil containing black granulating coal in their bottom layers.

\subsection{Soil and slag sample analyses}

The soil and slag samples were halved by applying the quartering method after removing foreign substances. One-half of each sample was dried at $30{ }^{\circ} \mathrm{C}$ to a constant weight in a thermostatic air-blower-driven drying closet and then sieved with a 10-mesh nylon sieve. The $\mathrm{pH}$ of each dry sieved sample (10.00 g of sample mixed with $25 \mathrm{ml}$ deionized water) was determined by a pen pH meter (SX620 type, Instrument Factory of Shanghai Sanxin, Shanghai, China) (Peng et al., 2018a, 2017, 2018b).

And then the contents of PTMs (i.e., As, $\mathrm{Cd}, \mathrm{Cr}, \mathrm{Cu}, \mathrm{Hg}, \mathrm{Pb}$, and $\mathrm{Zn}$ ) and $\mathrm{Al}$ are determined by an ICP-AES (America, Varian VISTA) and an ICP-MS (America, Agilent 7700x) in an accredited laboratory (ALS Minerals - ALS Chemex (Guangzhou) Co. Ltd.) (Peng et al., 2018a, 2017,2018 b). After grinding to 200 -mesh $(0.074 \mathrm{~mm})$, each soil and slag sample was digested in two methods (Zhang et al., 2020). Firstly, $0.25 \mathrm{~g}$ of each sample was digested by a concentrated acid mixture (a ratio of 1: 2.5: 2: 2.5 for the $\mathrm{HClO}_{4}: \mathrm{HNO}_{3}: \mathrm{HF}: \mathrm{HCl}$ ) in an oven at $\sim 190{ }^{\circ} \mathrm{C}$ for $48 \mathrm{~h}$, cooled to room temperature, heated on a preheated hot plate $\left(150^{\circ} \mathrm{C}\right)$ under a fume hood to get rid of excess acid until crystalline solid was formed, and then diluted to a steady volume $(12.5 \mathrm{~mL})$ with $2 \%$ hydrochloric acid. Secondly, $0.5 \mathrm{~g}$ of each sample was dissolved in aqua regia method (a ratio of 1:3 for $\mathrm{HNO}_{3}: \mathrm{HCl}$ ) in an oven at $\sim 190{ }^{\circ} \mathrm{C}$ for $48 \mathrm{~h}$, and then was placed 
133 and heated on a preheated hot plate $\left(150^{\circ} \mathrm{C}\right)$ under a fume hood until white fumes appeared and 134 crystalline solid was formed. Afterward, the crystalline solid was dissolved and precisely 135 adjusted to a stable volume $(12.5 \mathrm{~mL})$ with deionized water.

\section{$136 \quad 2.3$ Data statistics and analyses}

\section{2.3.1 Pollution index}

138 Pollution index (PI) is a useful tool to express the degree of harm that is the ratio of the 139 measured PTM content in the soil to the standard value of the PTM as follows:

$$
\mathrm{PI}=\frac{C_{i}}{C_{0}}
$$

141 where $C_{i}$ and $C_{0}$ represent the PTM content of the soil sample and its standard value of the PTM, 142 respectively. Although many researchers used their local geochemical background as the element 143 standard values, we selected the risk-based screening values for the soil contamination of 144 agricultural land (MEE and SAMR, 2018) (Table S1) as the element standard values. Because 145 the former is its average value of the research area and maybe cause more errors to estimate the 146 pollution. And the latter is the limited value for the soil contamination of agricultural land and 147 could judge its contamination.

\section{$148 \quad$ 2.3.2 Enrichment factor}

149 Enrichment factor (EF) is the relative abundance of an element, and it is a useful tool to 150 differentiate the source of a chemical element, i.e., whether the source is anthropogenic or natural (Zhang et al., 2014; Peng et al., 2017, 2018b). The EF is calculated as follows:

$$
\mathrm{EF}=\frac{\left(\frac{\mathrm{Me}}{\mathrm{Al}}\right)_{\text {soil }}}{\left(\frac{\mathrm{Me}}{\mathrm{Al}}\right)_{\text {crust }}}
$$

153 Here, $(\mathrm{Me} / \mathrm{Al})_{\text {soil }}$ and $(\mathrm{Me} / \mathrm{Al})_{\text {crust }}$ refer to the soil and mean crustal content (Taylor, 1964) (Table 154 S1) ratios, respectively, of a PTM and Al.

\section{$155 \quad$ 2.3.3 Transfer coefficient}

156 Transfer coefficient (TC) is a useful tool to understand the element changes in a soil profile 157 during natural weathering and the degree of element migration or enrichment. It could be used to 158 calculate the loss or increase of elements in rock and soil during weathering (Nesbitt, 1979, 159 Nesbitt et al., 1980; Brimhall et al., 1985; Brimhall and Dietrich, 1987; Brimhall et al., 1991, 160 1992; Brantley and White, 2009; Zhang et al., 2018). The TC is calculated as follows: 
161

162

163

164

165

166

167

168

169

170

171

172

173

174

175

176

177

178

179

180

181

182

183

184

185

186

187

188

189

190

$$
T C=\frac{C_{i p}}{C_{i w}} \frac{C_{j w}}{C_{j p}}-1
$$

Here, the $\mathrm{TC}<0$ and $\mathrm{TC}>0$ is respective the fraction of a mobile element or mineral $j$ lost or gained assuming that element or mineral $i$ is immobile. $C$ is the parent and weathered material element concentration ( $w$ and $p$ present to the weathered and parent material respectively). The soil element content could be normalized by the content of an assumed immobile element $\mathrm{Ti}$ (Anderson et al., 2002; Brantley and White, 2009; Hausrath et al., 2009), Zr (Tian and Liu, 1995; Anderson et al., 2002; Brantley and White, 2009; Hausrath et al., 2009), Nb (Anderson et al., 2002; Brantley and White, 2009), Fe (Hausrath et al., 2009), Sc (Zhang et al., 2019) or Al (Tian and Liu, 1995; Hausrath et al., 2009) to calculate the fractional mineral loss or enrichment (Anderson et al., 2002; Brantley and White, 2009). In the chemical weathering process, $\mathrm{Al}$ is highly stable, and it is a good reference by which to measure the geochemical behavior of other elements (Chen et al., 1997). Therefore, $\mathrm{Al}$ is assumed to be the immobile element in this study.

\section{Results}

\subsection{PTM concentrations and soil pH value in the weathering profiles (slag-covered and} slag-absent)

The soil $\mathrm{Cd}, \mathrm{Pb}, \mathrm{Zn}$ concentrations might be mainly affected by these of the covered slag, other soil PTM contents and soil $\mathrm{pH}$ values are little or no affected by the covered slag. As shown in Table $\mathrm{S} 1$, the concentrations of soil $\mathrm{As}, \mathrm{Cd}, \mathrm{Cr}, \mathrm{Cu}, \mathrm{Hg}, \mathrm{Pb}$, and $\mathrm{Zn}$ in the slag-covered section respectively range from 0.5 to 14.8 (mean 4.45), 0.61 to 4.59 (1.79), 59 to 77 (68.09), 102.0 to 164.0 (146.36), 0.025 to 0.090 (0.058), 7.7 to 191.5 (41.82) and 127 to 367 (231.36) $\mathrm{mg} / \mathrm{kg}$, and its $\mathrm{pH}$ values ranges from 4.42 to 5.22 (4.82). And their concentrations in the slagabsent section respectively range from 0.2 to 7.8 (mean 4.95), 0.14 to $1.82(0.45), 49$ to 94 (73.40), 84.5 to 135.0 (125.35), 0.027 to 0.110 (0.068), 5.7 to 19.6 (12.97), 61 to 202 (137.70) $\mathrm{mg} / \mathrm{kg}$, and its $\mathrm{pH}$ values ranges from 4.46 to 5.12 (4.94). These show that the soil $\mathrm{Cd}, \mathrm{Pb}, \mathrm{Zn}$ concentrations of the slag-covered section are notable higher than these of the slag-absent section, and the $\mathrm{As}, \mathrm{Cr}, \mathrm{Cu}$ and $\mathrm{Hg}$ concentrations and $\mathrm{pH}$ values of the soil in the slag-covered section are smilar to these of the slag-absent section. Additionally, the concentrations of $\mathrm{As}, \mathrm{Cd}, \mathrm{Cr}, \mathrm{Cu}$, $\mathrm{Hg}, \mathrm{Pb}, \mathrm{Zn}$ of the slag are respective 636, 192.0, 68, 499, 0.098, 10550.0, and $16450 \mathrm{mg} / \mathrm{kg}$, and its $\mathrm{pH}$ value is 6.83 . The slag $\mathrm{As}, \mathrm{Cd}, \mathrm{Cu}, \mathrm{Hg}, \mathrm{Pb}, \mathrm{Zn}$ concentrations are more than these in the 
191 soil, and its $\mathrm{pH}$ value is very higher than the soil $\mathrm{pH}$ values of its bottom weathering profile. So, 192 the slag $\mathrm{Cd}, \mathrm{Pb}, \mathrm{Zn}$ concentrations might impact these of its bottom weathering profile, and other 193 PTM contents and pH value of the slag might be a little or no impact to these of its bottom 194 weathering profile.

\section{3.2 PTM distribution in the weathering profiles (slag-covered and slag-absent)}

The soil $\mathrm{As}$ and $\mathrm{Pb}$ respective within $30 \mathrm{~cm}$ and $50 \mathrm{~cm}$ depth, and all soil $\mathrm{Cd}$ and $\mathrm{Zn}$ in the

197

198

199

200

201

202

203

204

205

206

207

208

209

210

211

212

213

214

215

216

217

218

219

220

221

slag-covered weathering profile are remarkably contaminated by the indigenous zinc smelting slag. And the soil $\mathrm{Cr}, \mathrm{Cu}$, and $\mathrm{Hg}$ of the slag-covered weathering profile might be little or no impacted by their covered slag. As shown in Figure 1, the soil As and $\mathrm{Pb}$ contents respective within $30 \mathrm{~cm}$ and $50 \mathrm{~cm}$ depth, and all soil $\mathrm{Cd}$ and $\mathrm{Zn}$ concentrations in the slag-covered weathering profile are notably greater than those in the soil of the slag-absent section. These show that soil $\mathrm{As}$ and $\mathrm{Pb}$ respective within $30 \mathrm{~cm}$ and $50 \mathrm{~cm}$ depth, all soil $\mathrm{Cd}$ and $\mathrm{Zn}$ in the slag-covered weathering core, are remarkably polluted by the covered slag. However, there is little difference in the contents and change trends of $\mathrm{Cr}, \mathrm{Cu}$ and $\mathrm{Hg}$ in the two weathering profiles (slag-covered and slag-absent). It shows that $\mathrm{Cr}, \mathrm{Cu}$ and $\mathrm{Hg}$ in the whole slag-covered weathering profile might be little or no impacted by the covered slag.

Figure 1 Potentially toxic metal(loid) distribution in both slag-covered and slag-absent weathering profile in the study area

Moreover, the soil $\mathrm{As}, \mathrm{Cd}, \mathrm{Pb}$, and $\mathrm{Zn}$ distribution of the slag-covered profile show they have an abrupt change with increasing soil depths, and they are different abrupt depths with different PTMs (Figure 1). These abrupt changes might be caused by the $\mathrm{As}, \mathrm{Cd}, \mathrm{Pb}$, and $\mathrm{Zn}$ downward in the slag. There are different PTM mobility of the soil in different soil depths due to the soil physical and chemical properties ( $\mathrm{pH}$, texture, etc. (Ettler et al., 2007)). It might be the reason why these PTMs have different abrupt depths in this research area.

Additionally, the soil $\mathrm{Hg}$ distribution of the two weathering profiles is similar to the Liu et al. (2006) result. It shows a convex or irregular distribution (enrichment in the surface, middle, and bottom layers to a certain extent). These explain that the soil $\mathrm{Hg}$ is polluted by industrial actives. Also, this similarity might be caused by $\mathrm{Hg}$ contamination from the soot produced during the smelting process is more seriously than $\mathrm{Hg}$ contamination from the slag (Protano and Nannoni, 2018). Because $\mathrm{Hg}$ in the original ore mainly evaporates first and diffuses into the 
222 surrounding environment through the indigenous zinc smelting soot due to the low melting point 223 and boiling point of $\mathrm{Hg}$. Therefore, the soil $\mathrm{Hg}$ concentration in the two weathering profiles is 224 mainly contaminated by the indigenous zinc smelting soot but not the slag.

225

226

227

228

229

230

231

232

233

234

235

236

237

238

239

240

241

242

243

244

245

246

247

248

249

250

251

252

\subsection{PTM migration in the weathering profiles (slag-covered and slag-absent)}

The absolute content change of elements could not reflect their authentical geochemical behavior in the weathering and soil formation process. The mobile element leaching could make the immobile element enrich (Chen et al., 1997). It explains that the immobile element content might not reflect the authentical phenomenon of element migration or enrichment during the chemical weathering process. The $\mathrm{TC}>0, \mathrm{TC}<0$, and $\mathrm{TC}=0$ indicate that the element is enriched, depleted, and immobile relative to the parent, respectively (Brantley and White, 2009; Hausrath et al., 2011). Also, the PTM proportion of the parent soil materials is on the foundation of their TC calculation of soil profiles. So there should be regarded theoretically as the effect of the element migration and redistribution in the soil geochemical process during the soil formatting and weathering process of the soil cores that any circumstance beyond the range of the TC value deviating from the total error due to analysis and determination (Tian and Liu, 1995). Therefore, when $\mathrm{TC} \approx 0$, the proportion of the element to its reference element in the soil maintains the parent material characteristics. And there is no notable element migration during the process of soil formation. When $\mathrm{TC}$ is significantly greater than 0 , it indicates that the element is notably enriched relative to the parent. When TC is significantly lower than 0 , it means that the element is remarkably depleted relative to the parent.

According to field observations, there is spring water near the weathering profile. And its elevation slightly lower than at the bottom layer elevation of the soil profile. These indicate that the groundwater level is relatively shallow (approximately the dept at $240 \mathrm{~cm}$ ) in this research area. So, their bottom layer might be easily affected by the rising effect of groundwater capillary water. Additionally, the soil texture and color of the two bottom layers of the two weathering profiles are significantly different from their upper layers (Table S1). The two bottom layers of the soil profiles (slag-covered and slag-absent) are dark gray soil. These might be caused by the lower coal layer becoming soaked with upward capillary movement from a shallow water table (Huang and Xu, 2010; Weil and Brady, 2016). Therefore, the penultimate layer might be a little affected by the bottom layer. And we chose the reciprocal third layer in the slag-absent profile as the reference of the parent layer in this study. The transfer coefficients of the PTMs in the two 
253 weathering profiles are presented in Figure 2.

254 Figure 2 Transfer coefficients of potentially toxic metal(loid)s in both slag-covered and slag-absent weathering 255 profile in the study area

256

257

258

259

260

261

262

263

264

265

266

267

268

269

270

271

272

273

274

275

276

277

278

279

280

281

282

283

The soil As distribution is notably enriched within $110 \mathrm{~cm}$ depth in the slag-covered weathering profile. And its enrichment within $30 \mathrm{~cm}$ depth is remarkably higher than that in the slag-absent section. Additionally, the soil As content at soil depths between 50 and $190 \mathrm{~cm}$ in the slag-covered core is less than that in the slag-absent profile. The soil As is prominently depleted at soil depths ranged from 110 to $190 \mathrm{~cm}$ in the slag-covered core but not in the slag-absent section. According to yield observations, some plants are growing in the lower part of the slagcovered profile but not in the slag-absent section. Therefore, the soil As distribution difference might be related to the redistribution and biological absorption of As in the soil profile (Brantley and White, 2009).

The soil $\mathrm{Cd}$ is significantly enriched to varying enrichment degrees in the slag-covered profile, and the $\mathrm{Cd}$ content and enrichment degree are higher than those of the slag-absent core.

The soil $\mathrm{Cr}$ is completely depleted except for some enrichment in the bottom layer of the slag-covered core. It is no significant migration phenomenon in the slag-absent profile except for the soil layer at depths of 30 to $55 \mathrm{~cm}$ and 55 to $80 \mathrm{~cm}$, and in the bottom layer.

The soil $\mathrm{Cu}$ shows no notable migration of the whole slag-covered profile. And it also shows no significant migration in the slag-absent section, except for a slight depletion at a depth of 30 to $130 \mathrm{~cm}$ and a light enrichment in the bottom layer.

The soil Hg is notably enriched within $110 \mathrm{~cm}$ depth and the bottom soil layer of the slagcovered core, and its enrichment degree is not higher than that in the slag-absent profile.

The soil $\mathrm{Pb}$ is remarkably enriched throughout the two soil profiles, and the $\mathrm{Pb}$ enrichment degree within $50 \mathrm{~cm}$ depth in the slag-covered core is higher than that in the slag-absent section.

The soil $\mathrm{Zn}$ is prominently enriched in the whole slag-covered profile, and its enrichment degree is higher than those in the slag-absent core.

These results show that the soil $\mathrm{As}$ and $\mathrm{Pb}$ respective within at least $30 \mathrm{~cm}$ and $50 \mathrm{~cm}$ depth, all soil $\mathrm{Cd}$ and $\mathrm{Zn}$ in the slag-covered core are affected by the downward migrations of those elements from the slag. However, the soil $\mathrm{Cr}, \mathrm{Cu}$ and $\mathrm{Hg}$ of the slag-covered section might not be affected by the slag. Therefore, the slag PTM migration depths are different in the slag- 
284 covered weathering profile (i.e., the soil $\mathrm{As}$ and $\mathrm{Pb}$ correspond to within at least $30 \mathrm{~cm}$ and 50 $285 \mathrm{~cm}$ depth, all soil $\mathrm{Cd}$ and $\mathrm{Zn}$ in the slag-covered core).

286

\section{Discussion}

288

289

290

291

292

293

294

295

296

297

298

299

300

301

302

303

304

305

306

307

308

309

310

311

312

313

\subsection{PTM contamination in the soil profile impacted by the slag}

The PI was introduced to evaluate and better understand the PTM contamination of soil profiles in indigenous zinc smelting areas in this research. A PI value greater than 1 indicates that the soil sample is polluted, while a PI value less than 1 suggests that the soil sample is unpolluted ( $\mathrm{Li}$ et al., 2006). The $1<\mathrm{PI}<3,3<\mathrm{PI}<5$, and PI $>5$ suggest that the soil is slightly polluted, moderately polluted, and seriously polluted, respectively (Wu et al., 2015).

As shown in Table 1, the PIs of the slag As, $\mathrm{Cd}, \mathrm{Cu}, \mathrm{Pb}$, and $\mathrm{Zn}$ are greater than 5. It indicates that these PTM contents of the slag reach seriously polluted levels. If crops are planted on the slag, these PTMs are at risk of causing obvious pollution. The PIs of the slag $\mathrm{Cr}$ and $\mathrm{Hg}$ are less than 1, which indicates that their contents are required for their risk-based screening values for the soil contamination of agricultural land and that their contents are unpolluted. In the slag-covered soil profile, the PIs of soil As, $\mathrm{Cr}$, and $\mathrm{Hg}$ are less than 1, which indicates that their contents do not exceed the screening values of environmental pollution risk for agricultural land and do not reach the pollution level. The PIs of soil $\mathrm{Cd}$ and $\mathrm{Cu}$ are distributed in the ranges of 1 to 3,3 to 5, and greater than 5, indicating that these PTMs are slightly, moderately, and moderately polluted, respectively. The PIs of soil $\mathrm{Pb}$ within $30 \mathrm{~cm}$ depth and $\mathrm{Zn}$ in most soil samples range from 1 to 3 , which indicate that their contents exceed the screening value of pollution risk in soil environmental quality and reach a slight contamination level. In the slagabsent soil profile, the PIs of soil $\mathrm{As}, \mathrm{Cr}, \mathrm{Hg}$, and $\mathrm{Pb}$ in the whole core and $\mathrm{Cd}$ and $\mathrm{Zn}$ in most soil samples are all less than 1 . These mean that their contents do not exceed the screening value of pollution risk in soil environmental quality and do not reach a pollution level. There indicate that their contents are at a slight contamination level that the PIs of $\mathrm{Cu}$ in the whole core, $\mathrm{Cd}$ in soil within $30 \mathrm{~cm}$ depth, and $\mathrm{Zn}$ in surface soil range from 1 to 3 . Therefore, the soil $\mathrm{Cd}$ and $\mathrm{Cu}$ in the whole profile, the soil $\mathrm{Pb}$ within $30 \mathrm{~cm}$ depth, and $\mathrm{Zn}$ in most soil samples are contaminated to a certain extent in the slag-covered weathering profile. And the soil $\mathrm{Cd}$ within $30 \mathrm{~cm}$ depth, the $\mathrm{Zn}$ of surface soil, and all soil $\mathrm{Cu}$ in the slag-absent weathering core are slightly 
314 polluted.

315 Table 1 Pollution index of potentially toxic metal(loid)s in both slag-covered and slag-absent weathering

profile in the study area

318

319

320

321

322

323

324

325

326

327

328

329

330

331

332

333

334

335

336

337

338

339

340

341

342

343

344

\subsection{PTM source in the soil profile impacted by the slag}

According to Sutherland (2000) and Chen et al. (2007), $E F<1,1 \leq E F<3,3 \leq E F<5$, $5 \leq E F<10,10 \leq E F<25,25 \leq E F<50$ and $E F \geq 50$ correspond to no enrichment, minor enrichment, moderate enrichment, moderately severe enrichment, severe enrichment, very severe enrichment, and extremely severe enrichment, respectively. The EFs of the PTMs could help further trace their sources in the soil (Hu et al., 2013; Peng et al., 2017). Although the element contents are mainly affected by parent rock types (Yang et al., 2010; 2011; Peng et al., 2017), elemental anomalies are mainly affected by specific natural geographical backgrounds (Yu et al., 2014) and by the effects of anthropogenic activities (Yu et al., 2014; Peng et al., 2017). The soil PTM contaminations might also be easily affected by anthropogenic activities, especially in surface soil (Peng et al., 2017). Moreover, an EF of less than one or greater than three indicates that the element originated predominantly from natural sources and anthropogenic activities, respectively (Hu et al., 2013). An EF value between 1 and 3 shows that the element is affected by both natural sources and anthropogenic activities.

As shown in Table 2, in the slag-covered weathering profile, the EFs of the soil As within $30 \mathrm{~cm}$ depth, the soil $\mathrm{Pb}$ and $\mathrm{Zn}$ within $50 \mathrm{~cm}$ depth, $\mathrm{Cd}$ in most soil samples are greater than 3 ; the EFs of $\mathrm{As}, \mathrm{Cd}$ and $\mathrm{Pb}$ in a few soil samples, all soil $\mathrm{Cu}$, and $\mathrm{Zn}$ in most soil samples range from 1 to 3; other EFs are less than 1. In the slag-absent soil core, the EFs of the soil As within $105 \mathrm{~cm}$ depth and the soil $\mathrm{Cd}$ in the surface and bottom layers are greater than 3, the EFs of As, $\mathrm{Cd}, \mathrm{Hg}$, and $\mathrm{Pb}$ in a few soil samples and $\mathrm{Cu}$ and $\mathrm{Zn}$ in the whole section range from 1 to 3 , and other EFs are less than 1. These results show that $\mathrm{As}, \mathrm{Cd}, \mathrm{Pb}$, and $\mathrm{Zn}$ are mainly from anthropogenic activities contamination (i.e., the indigenous zinc smelting slag) at different depths of the slag-covered profile in the clastic rock district. Additionally, the $\mathrm{As}, \mathrm{Cd}$, and $\mathrm{Pb}$ in a few soil samples, the $\mathrm{Cu}$ in the whole core, and the $\mathrm{Zn}$ in most soil samples of the slag-covered profile are mainly affected by human activities and natural weathering sources. Moreover, the soil $\mathrm{Cd}, \mathrm{Cr}, \mathrm{Cu}, \mathrm{Hg}$, and $\mathrm{Pb}$ contents of the bottom layer are higher than those in the reciprocal third soil layer of the two weathering profiles. And the soil texture and color of the two bottom 
345 layers are significantly different from the upper soil in the weathering profiles. These might be

346 caused by the upward capillary movement contaminations of the coal seam (below the bottom

347 layer of the two weathering profiles). Therefore, the contents of PTMs (i.e., $\mathrm{Cd}, \mathrm{Cu}, \mathrm{Pb}$, and $\mathrm{Zn}$ )

348 in the slag-covered profile are greatly affected by human activities (especially by the slag), while

349 the $\mathrm{Cd}, \mathrm{Cu}, \mathrm{Hg}, \mathrm{Pb}$, and $\mathrm{Zn}$ contents of the upper part in the slag-absent core might be affected 350 by smelting activities.

351 Table 2 Enrichment factors of potentially toxic metal(loid)s in both slag-covered and slag-absent weathering

profile in the study area

353

354

355

356

357

358

359

360

361

362

363

364

365

366

367

368

369

370

371

372

373

374

375

\subsection{PTM migration and its influence in the soil profile impacted by the slag}

Some PTMs might be released by natural weathering and entered into the surrounding environment by leaching rain. Some PTMs (i.e., $\mathrm{As}, \mathrm{Cd}, \mathrm{Cu}, \mathrm{Hg}, \mathrm{Pb}$, and $\mathrm{Zn}$ ) of the slag are very high and more than these in the soil of its bottom weathering profile (Table S1). Although most of the slag PTMs are generally dominated by polymetallic or other phases (Ettler et al., 2003; Scokart et al., 1983; Sobanska et al., 2016), they could be easily transported to the surrounding circumstances due to long-term natural weathering (Sobanska et al., 2016; Tyszka et al., 2014; 2018) or other processes occurring in acidic environments (Scokart et al., 1983; Sobanska et al., 2016; Warchulski et al., 2019; Yang et al., 2006). There adds to the bioavailability of Cd that a possible transformation of $\mathrm{Cd}$ from metal oxides in smelting slags to adsorbed phases and carbonates (Wang et al., 2020). Warchulski et al. prove the importance of rainfall-induced weathering on PTMs mobilization and migration (Warchulski et al., 2019).

Some PTMs of the slag might be migrated downward and contaminated the groundwater by leaching and infiltration through the soil profile in the clastic rock distribution district. The contents of some PTMs (i.e., $\mathrm{Cd}, \mathrm{Cu}, \mathrm{Pb}$, and $\mathrm{Zn}$ ) in the slag-covered weathering profile are greatly affected by the covered slag in this research area. As described in Figure 2, the soil As and $\mathrm{Pb}$ respective within at least $30 \mathrm{~cm}$ and $50 \mathrm{~cm}$ depth, all soil $\mathrm{Cd}$ and $\mathrm{Zn}$ in the slag-covered weathering profile are affected by the slag. And the groundwater level is relatively shallow (approximately the dept at $240 \mathrm{~cm}$ ) in the research area through field observations. Additionally, many leaching experiments show that some PTMs in the slag could easily migrate into the surrounding environment (Zhu et al., 2012; Piatak et al., 2015; Liu et al., 2018; Tyszka et al., 2018; Warchulski et al., 2019). The Cd and Zn migrate with organic matter that brings about 
376 more potential hazards of the groundwater movements near zinc smelters in acidic sandy soils 377 (Scokart et al., 1983). Groundwater quality is mostly poor near the Pb-Zn mining and smelter 378 and coal mining districts in Hezhang County where borders on Weining Prefecture in Guizhou 379 Province (Zhao et al., 2016). The heavy $\mathrm{Zn}$ isotopic signatures in the groundwater might be 380 concerned to seepage from the slag piles by the advective or diffusive transport of pore water 381 from the polluted soil at the smelting site (Yin et al., 2016).

382 Therefore, over time, some slag PTMs (especially $\mathrm{Cd}$ and $\mathrm{Zn}$ ) would be released by natural 383 weathering and re-migrated into the soil of its bottom weathering profile by leaching rain, and 384 eventually infiltrate into deeper soil, and even might contaminate the groundwater.

385

386

\section{Conclusions}

387

388

In the clastic rock region, the soil $\mathrm{Cd}$ and $\mathrm{Cu}$ in the whole profile, the soil $\mathrm{Pb}$ within $30 \mathrm{~cm}$ depth, and $\mathrm{Zn}$ in most soil samples are to a certain extent at pollution levels in the slag-covered 389 weathering profile. All soil $\mathrm{Cu}$, the soil $\mathrm{Cd}$ within $30 \mathrm{~cm}$ depth, and $\mathrm{Zn}$ in the surface soil in the slag-absent section are slightly contaminated. The contents of PTMs (i.e., $\mathrm{Cd}, \mathrm{Cu}, \mathrm{Pb}$, and $\mathrm{Zn}$ ) 391 are greatly affected by human activities (especially by the slag) in the slag-covered profile. And the contents of PTMs (i.e., $\mathrm{Cd}, \mathrm{Cu}, \mathrm{Hg}, \mathrm{Pb}$, and $\mathrm{Zn}$ ) in the upper part of the slag-absent core might be affected by the indigenous zinc smelting activities.

Additionally, the contents of the soil $\mathrm{As}$ and $\mathrm{Pb}$ respective within $30 \mathrm{~cm}$ and $50 \mathrm{~cm}$ depth, 395

all soil $\mathrm{Cd}$ and $\mathrm{Zn}$ in the slag-covered weathering core are higher than those in the slag-absent profile. And the soil As is enriched within $110 \mathrm{~cm}$ depth (especially within $30 \mathrm{~cm} \mathrm{depth).} \mathrm{All} \mathrm{soil}$ $\mathrm{Cd}, \mathrm{Pb}$, and $\mathrm{Zn}$ are enriched to varying degrees in the whole slag-covered profile (especially the soil $\mathrm{Pb}$ within $50 \mathrm{~cm}$ depth).

Moreover, the soil $\mathrm{As}, \mathrm{Cd}, \mathrm{Pb}$, and $\mathrm{Zn}$ of the slag-covered soil profile are affected by the 401 slag in the clastic rock region, and their affected depths and degrees are different. The soil As and $\mathrm{Pb}$ respective within $30 \mathrm{~cm}$ and $50 \mathrm{~cm}$ depth, and all soil $\mathrm{Cd}$ and $\mathrm{Zn}$ in the slag-covered 402 profile are remarkably affected by the downward migration of these PTMs from the slag. All soil $\mathrm{Cr}, \mathrm{Cu}$, and $\mathrm{Hg}$ of the slag-covered section are not or are little affected by the slag. Additionally, with time, some PTMs (especially $\mathrm{Cd}$ and $\mathrm{Zn}$ ) of the slag might contaminate the groundwater by 405 leaching and infiltration through the soil profile in the clastic rock region. Therefore, there 
407 contamination of the soil and the groundwater in the research area by PTMs.

408

409

410

411

412

413

414

415

416

417

418

419

420

421

422

423

424

425

426

427

428

429

430

431

432

433

434

435

436

437

438

439

440

441

442

443

\section{Acknowledgements}

This project was financially supported by the National Natural Science Foundation of China (Grant Nos. 41463009), the Postgraduate Research Foundation of Guizhou Province (Contract No. QJYH-KYJJ-2016-05), the Public and Basic Geological Project of Guizhou Province (No. QGTZF-2015-20), the Scientific Research Project for Introducing Talents into Guizhou University (GDRJHZ[2019]05), the Foundation for Innovative Major Research Groups of the Education Bureau in Guizhou Province (QJH-KY-2016-024) and the Construction Project of the First-Class Subjects "Ecology" in Guizhou Province (GNYL[2017]007). We are very grateful to the anonymous reviewers for their helpful comments and constructive criticisms of both the English and the technical writing of this manuscript.

\section{References}

Anderson, S. P., Dietrich, W. E., Jr, G. H. B., 2002. Weathering profiles, mass-balance analysis, and rates of solute loss: Linkages between weathering and erosion in a small, steep catchment. Geological Society of America Bulletin, 114(9), 1143-1158.

Baize, D., 1994. Teneurs totales en métaux lourds dans les sols français. Le Courrier de l'environnement de l'INRA, 22(22), 37-46.

Bi, X., Feng, X., Yang, Y., Qiu, G., Li, G., Li, F., Liu, T., Fu, Z., Jin, Z., 2006. Environmental contamination of heavy metals from zinc smelting areas in Hezhang County, western Guizhou, China. Environment international, 32(7), 883-890.

Brantley, S. L., White, A. F., 2009. Approaches to Modeling Weathered Regolith. Reviews in Mineralogy \& Geochemistry, 70(1), 435-484.

Brimhall, G. H., Alpers, C. N., Cunningham, A. B., 1985. Analysis of supergene ore-forming processes and ground-water solute transport using mass balance principles. Economic Geology, 80(5), 1227-1256.

Brimhall, G. H., Chadwick, O. A., Lewis, C. J., Compston, W., Williams, I. S., Danti, K. J., Dietrich, W. E., Power, M. E., Hendricks, D., Bratt, J., 1992. Deformational mass transport and invasive processes in soil evolution. Science, 255(5045), 695.

Brimhall, G. H., Dietrich, W. E., 1987. Constitutive mass balance relations between chemical composition, volume, density, porosity, and strain in metasomatic hydrochemical systems: Results on weathering and pedogenesis. Geochimica et Cosmochimica Acta, 51(3), 567-587.

Brimhall, G. H., J, L. C., Ford, C., Bratt, J., 1991. Quantitative geochemical approach to pedogenesis: importance of parent material reduction, volumetric expansion, and eolian influx in lateritization. Geoderma, 51(1), 51-91. 
444 Chen, C. W., Kao, C. M., Chen, C. F., Dong, C. D., 2007. Distribution and accumulation of

445

446

447

448

449

450

451

452

453

454

455

456

457

458

459

460

461

462

463

464

465

466

467

468

469

470

471

472

473

474

475

476

477

478

479

480

481

482 heavy metals in the sediments of Kaohsiung Harbor, Taiwan. Chemosphere, 66(8), 14311440.

Chen, J., Ji, J., Qiu G., Lu, H., Zhu, H., 1997. Geochemistry study on chemical weathering degree of loess in in Luochuan County, Shuanxi Province. Science in China Series Dearth Sciences. 27(6): 531-536. (In Chinese)

Ettler, V., Piantone, P., Touray, J. C., 2003. Mineralogical control on inorganic contaminant mobility in leachate from lead-zinc metallurgical slag: experimental approach and longterm assessment. Mineralogical Magazine, 67(6), 1269-1283.

Ettler, V., Rohovec, J., Navrátil, T., Mihaljevič, M., 2007. Mercury Distribution in Soil Profiles Polluted by Lead Smelting. Bulletin of Environmental Contamination and Toxicology, 78(1), 13-17.

Hausrath, E. M., Navarre-Sitchler, A. K., Sak, P. B., Williams, J. Z., Brantley, S. L., 2011. Soil profiles as indicators of mineral weathering rates and organic interactions for a Pennsylvania diabase. Chemical Geology, 290(3-4), 89-100.

Hausrath, E. M., Neaman, A., Brantley, S. L., 2009. Elemental release rates from dissolving basalt and granite with and without organic ligands. American Journal of Science, 309(8), 633-660.

Hu, Y., Liu, X., Bai, J., Shih, K., Zeng, E. Y., Cheng, H., 2013. Assessing heavy metal pollution in the surface soils of a region that had undergone three decades of intense industrialization and urbanization. Environmental Science and Pollution Research, 20(9), 6150-6159.

Huang, C., Xiu, J., 2010. Pedology (Third Edition). Beijing: China Agriculture Press. (in Chinese)

Li, J., Xie, Z. M., Xu, J. M., Sun, Y. F., 2006. Risk assessment for safety of soils and vegetables around a lead/zinc mine. Environmental Geochemistry and Health, 28(1), 37-44.

Li, P., Lin, C., Cheng, H., Duan, X., Lei, K., 2015. Contamination and health risks of soil heavy metals around a lead/zinc smelter in southwestern China. Ecotoxicology and Environmental Safety, 113, 391-399.

Liu, H., Li, L., Pan, G., 2006. Profile distribution of total Cu, Pb, Hg, As in some paddy soils from the southern Jiangsu, China and the Influencing Factors. Journal of AgroEnvironment Science. 25(5): 1221-1227. (in Chinese with English Abstract)

Liu, T., Li, F., Jin, Z., Yang, Y., 2018. Acidic leaching of potentially toxic metals cadmium, cobalt, chromium, copper, nickel, lead, and zinc from two $\mathrm{Zn}$ smelting slag materials incubated in an acidic soil. Environmental Pollution, 238, 359-368.

Liu, Y., Wang, C., Liu, H., Ma, H., Zhang, Q., Feng, T., Sun, D., 2015. Spatial distribution and ecological risk assessment of heavy metals in soil around a lead and zinc smelter. Chinese Journal Environmental Engineering. 9(1): 477-484. (in Chinese with English Abstract) 
483

484

485

486

487

488

489

490

491

492

493

494

495

496

497

498

499

500

501

502

503

504

505

506

507

508

509

510

511

512

513

514

515

516

517

518

519

520

521

522

Ministry of Ecology and Environment of the People's Republic of China (MEE), State Administration for Market Regulation of the People's Republic of China (SAMR), 2018. Soil environmental quality risk control standard for soil contamination of agricultural land. GB 15168 - 2018, China Environment Press. (In Chinese)

Nesbitt, H. W., 1979. Mobility and fractionation of rare earth elements during weathering of a granodiorite. Nature, 279(5710), 206-210.

Nesbitt, H. W., Markovics, G., Price, R. C., 1980. Chemical processes affecting alkalis and alkaline earths during continental weathering. Geochimica et Cosmochimica Acta, 44(11), 1659-1666.

Peng, Y., Chen, J., Wei, H., Li, S., Jin, T., Yang, R., 2018a. Distribution and Transfer of Potentially Toxic Metal(loid)s in Juncus effusus from the Indigenous Zinc Smelting Area, Northwest Region of Guizhou Province, China. Ecotoxicology and Environmental Safety 152, 24-32.

Peng, Y., Chen, R., Yang, R., 2017. Analysis of heavy metals in Pseudostellaria heterophylla in Baiyi Country of Wudang District. Journal of Geochemical Exploration, 176, 57-63.

Peng, Y., Han, X., Chen, R., 2014. Ecological geology environment of pepper planting base in Dafang County of Guizhou Province. Guangdong Agriculture Science. 41(18): 127-131. (in Chinese with English Abstract)

Peng, Y., Yang, R., Jin, T., Chen, J., Zhang, J., 2018b. Risk assessment for potentially toxic metal(loid)s in potatoes in the indigenous zinc smelting area of northwestern Guizhou Province, China. Food and Chemical Toxicology, 120, 328-339.

Piatak, N. M., Parsons, M. B., Ii, R. R. S., 2015. Characteristics and environmental aspects of slag: A review. Applied Geochemistry, 57, 236-266.

Protano, G., Nannoni, F., 2018. Influence of ore processing activity on $\mathrm{Hg}$, As and $\mathrm{Sb}$ contamination and fractionation in soils in a former mining site of Monte Amiata ore district (Italy). Chemosphere, 199, 320-330.

Scokart, P. O., Meeus-Verdinne, K., De Borger, R., 1983. Mobility of heavy metals in polluted soils near zinc smelters. Water, Air, \& Soil Pollution, 20(4), 451-463.

Sobanska, S., Deneele, D., Barbillat, J., Ledésert, B., 2016. Natural weathering of slags from primary $\mathrm{Pb}-\mathrm{Zn}$ smelting as evidenced by Raman microspectroscopy. Applied Geochemistry, 64, 107-117.

Sterckeman, T., Douay, F., Proix, N., Fourrier, H., 2000. Vertical distribution of Cd, Pb and Zn in soils near smelters in the North of France. Environmental Pollution, 107(3), 377-389.

Sutherland, R., 2000. Bed sediment-associated trace metals in an urban stream, Oahu, Hawaii. Environmental Geology, 39(6), 611-627.

Taylor, S. R., 1964. Abundance of chemical elements in the continental crust: a new table. Geochimica Et Cosmochimica Acta, 28(8), 1273-1285.

Tian, J., Liu, P., 1995. Preliminary study on relative migration intensity of elements in soil profile of Loess Plateau. Research of Soil and water conservation, 2(4): 51-55. (in Chinese) 
523

524

525

526

527

528

529

530

531

532

533

534

535

536

537

538

539

540

541

542

543

544

545

546

547

548

549

550

551

552

553

554

555

556

557

558

559

560

561

Tyszka, R., Kierczak, J., Pietranik, A., Ettler, V., Mihaljevič, M., 2014. Extensive weathering of zinc smelting slag in a heap in Upper Silesia (Poland): potential environmental risks posed by mechanical disturbance of slag deposits. Applied Geochemistry, 40, 70-81.

Tyszka, R., Pietranik, A., Kierczak, J., Zieliński, G., Darling, J., 2018. Cadmium distribution in $\mathrm{Pb}-\mathrm{Zn}$ slags from Upper Silesia, Poland: Implications for cadmium mobility from slag phases to the environment. Journal of Geochemical Exploration, 186, 215-224.

Ullrich, S. M., Ramsey, M. H., Helios-Rybicka, E., 1999. Total and exchangeable concentrations of heavy metals in soils near Bytom, an area of $\mathrm{Pb} / \mathrm{Zn}$ mining and smelting in Upper Silesia, Poland. Applied Geochemistry, 14(2), 187-196.

Verner, J. F., Ramsey, M. H., Helios-Rybicka, E., Je`drzejczyk, B., 1996. Heavy metal contamination of soils around a $\mathrm{Pb}-\mathrm{Zn}$ smelter in Bukowno, Poland. Applied Geochemistry, 11(1), 11-16.

Wang, J., Jiang, Y., Sun, J., She, J., Yin, M., Fang, F., Xiao, T., Song, G., and Liu, J., 2020. Geochemical transfer of cadmium in river sediments near a lead-zinc smelter. Ecotoxicology and Environmental Safety, 196, 110529.

Wang, L., Lu, X., Li, L. Y., Ren, C., Luo, D., Chen, J., 2015. Content, speciation and pollution assessment of $\mathrm{Cu}, \mathrm{Pb}$ and $\mathrm{Zn}$ in soil around the lead-zinc smelting plant of Baoji, NW China. Environmental Earth Sciences, 73(9), 5281-5288.

Warchulski, R., Mendecki, M., Gawęda, A., Sołtysiak, M., and Gadowski, M., 2019. Rainwaterinduced migration of potentially toxic elements from a $\mathrm{Zn}-\mathrm{Pb}$ slag dump in Ruda Śląska in light of mineralogical, geochemical and geophysical investigations: Applied Geochemistry, 109, 104396.

Wei, X., Zhou, Y., Jiang, Y., Tsang, D.C.W., Zhang, C., Liu, J., Zhou, Y., Yin, M., Wang, J., Shen, N., Xiao, T., and Chen, Y., 2020, Health risks of metal(loid)s in maize (Zea mays $L$.) in an artisanal zinc smelting zone and source fingerprinting by lead isotope: Science of the Total Environment, 742, 140321.

Weil, R.R., and Brady, N.C., 2016. The Nature and Properties of Soils, 15th edition: England, Pearson Education Limited, 1-1105.

Wu, S., Peng, S., Zhang, X., Wu, D., Luo, W., Zhang, T., Zhou, S., Yang, G., Wan, H., Wu, L., 2015. Levels and health risk assessments of heavy metals in urban soils in Dongguan, China. Journal of Geochemical Exploration, 148, 71-78.

Yang, R., Ren, H., Long, J., Lang, X., 2011. Trace element and rare earth element content inmain rock-type weathering soil in Guizhou Province and eco-environment effect. J. Guizhou U. (Nat. Sci.) 28(6): 110-119 (In Chinese with English abstract).

Yang, T., Zhu, Z., Gao, Q., Rao, Z., Han, J., Wu, Y., 2010. Trace element geochemistry in topsoil from East China. Environmental Earth Sciences, 60(3), 623-631.

Yang, Y.-G., Jin, Z.-S., Bi, X.-Y., Li, F.-L., Sun, L., Liu, J., Fu, Z.-Y., 2009. Atmospheric Deposition-Carried $\mathrm{Pb}, \mathrm{Zn}$, and $\mathrm{Cd}$ from a Zinc Smelter and Their Effect on Soil Microorganisms. Pedosphere, 19(4), 422-433.

Peer) reviewing PDF | (2020:09:52804:1:1:NEW 29 Dec 2020) 
562

563

564

565

566

567

568

569

570

571

572

573

574

575

576

577

578

579

580

581

582

583

584

585

586

587

588

589

590

591

592

593

594

595

596

Yang, Y.-G., Liu, C.-Q., Wu, P., Zhang, G.-P., Zhu, W.-H., 2006. Heavy metal accumulation from zinc smelters in a carbonate rock region in Hezhang County, Guizhou Province. Water, Air, \& Soil Pollution, 174 (1), 321-339.

Yin, N.-H., Sivry, Y., Benedetti, M. F., Lens, P. N. L., van Hullebusch, E. D., 2016. Application of $\mathrm{Zn}$ isotopes in environmental impact assessment of $\mathrm{Zn}-\mathrm{Pb}$ metallurgical industries: A mini review. Applied Geochemistry, 64, 128-135.

Yu, H., Ni, S.-J., He, Z.-W., Zhang, C.-J., Nan, X., Kong, B., Weng, Z.-Y., 2014. Analysis of the spatial relationship between heavy metals in soil and human activities based on landscape geochemical interpretation. Journal of Geochemical Exploration, 146, 136-148.

Zhang, J., Yang, R., Li, Y.C., Peng, Y., Wen, X., and Ni, X., 2020, Distribution, accumulation, and potential risks of heavy metals in soil and tea leaves from geologically different plantations: Ecotoxicology and Environmental Safety, 195, 110475.

Zhang, H., Chen, J., Zhu, L., Yang, G., Li, D., 2014. Anthropogenic mercury enrichment factors and contributions in soils of Guangdong Province, South China. Journal of Geochemical Exploration, 144, 312-319.

Zhang, K., Ji, H., Zhu, H., Song, C., Wu, Y., 2018. Material sources and element migration characteristics of red weathering crusts in Southwestern Guizhou. Earth Environment, 46, 257-266. (in Chinese with English Abstract)

Zhang, W., Yu, R., Yang, Y., Hu, G., Cui, J., Yan, Y., Huang, H., 2019. Migration and source analysis of heavy metals in vertical soil profiles of the drylands of Xiamen City. Environment Science, 40, 3764-3773. (in Chinese with English Abstract)

Zhao, G., Xie, Y., Hong, T., Yu, Q., Tang, X., 2016. Spatial characteristics of mining and smelting effects on groundwater quality in Hezhang County, Guizhou Province, China, Earth and Environment. 44(2): 237-242. (in Chinese with English Abstract)

Zhou, G., Ma, S., Yu, J., Zhu, L., Wang, H., 2002. Vertical distribution of elements in soil profiles and their significance for geological and environmental. Geology and Exploration. 38(6): 70-75. (in Chinese with English Abstract)

Zhou, Y., Wang, L., Xiao, T., Chen, Y., Beiyuan, J., She, J., Zhou, Y., Yin, M., Liu, J., Liu, Y., Wang, Y., Wang, J., 2020. Legacy of multiple heavy metal(loid)s contamination and ecological risks in farmland soils from a historical artisanal zinc smelting area. Science of the Total Environment, 720, 137541.

Zhu, J., Liu, F., Wang, L., Li, J., 2012. Release characteristics of heavy metals from different types of waste residue in indigenous lead-zinc mining area in western Guizhou. Environmental Chemistry, 31(9), 1452-1453. (in Chinese with English Abstract)

Peer) reviewing PDF | (2020:09:52804:1:1:NEW 29 Dec 2020) 


\section{Table $\mathbf{1}$ (on next page)}

Pollution index of potentially toxic metal(loid)s in both slag-covered and slag-absent weathering profile in the study area 
1 Table 1 Pollution index of potentially toxic metal(loid)s in both slag-covered and slag-absent weathering profile in the study area

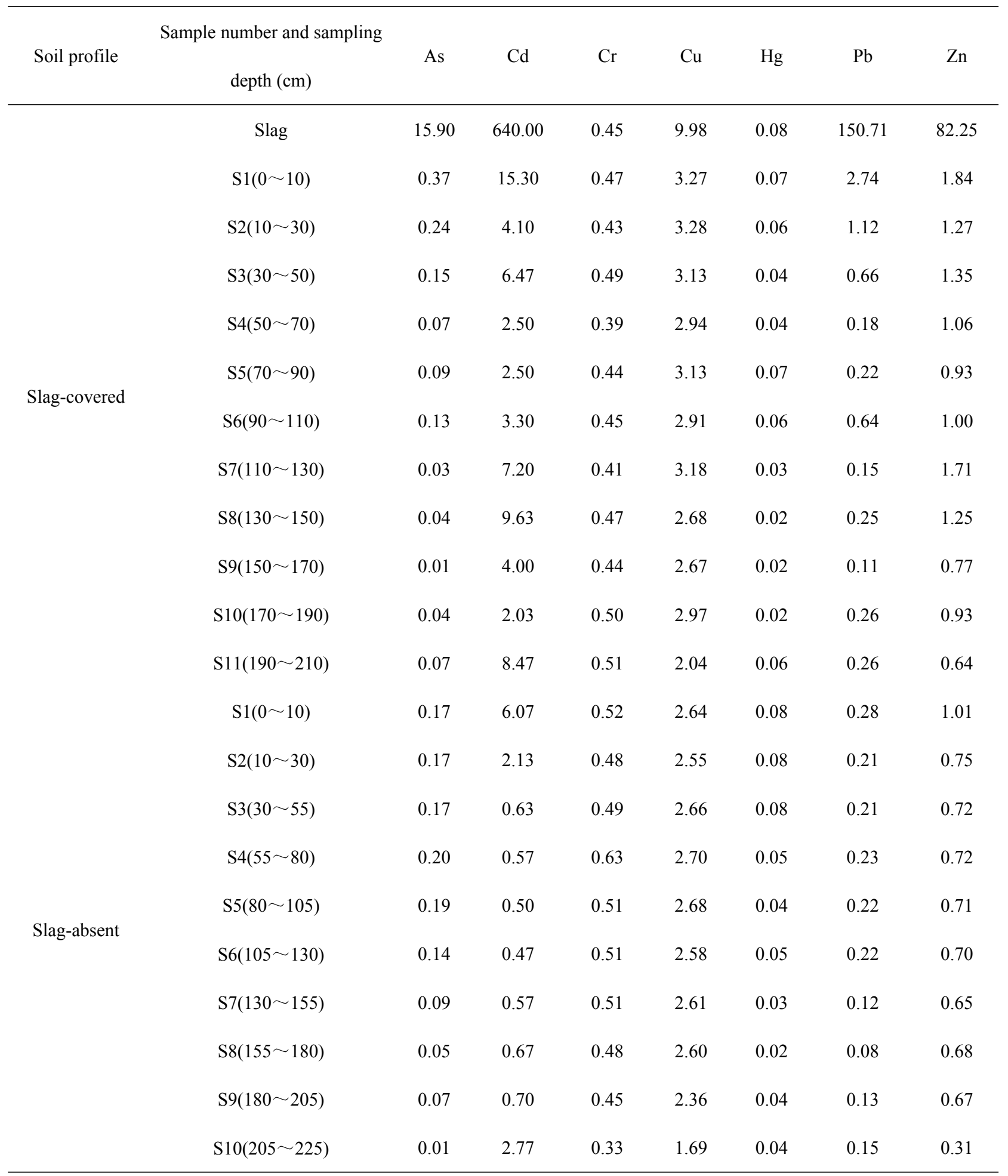




\section{Table 2 (on next page)}

Enrichment factors of potentially toxic metal(loid)s in both slag-covered and slag-absent weathering profile in the study area 
1 Table 2 Enrichment factors of potentially toxic metal(loid)s in both slag-covered and slag-absent weathering profile in the study 2

area

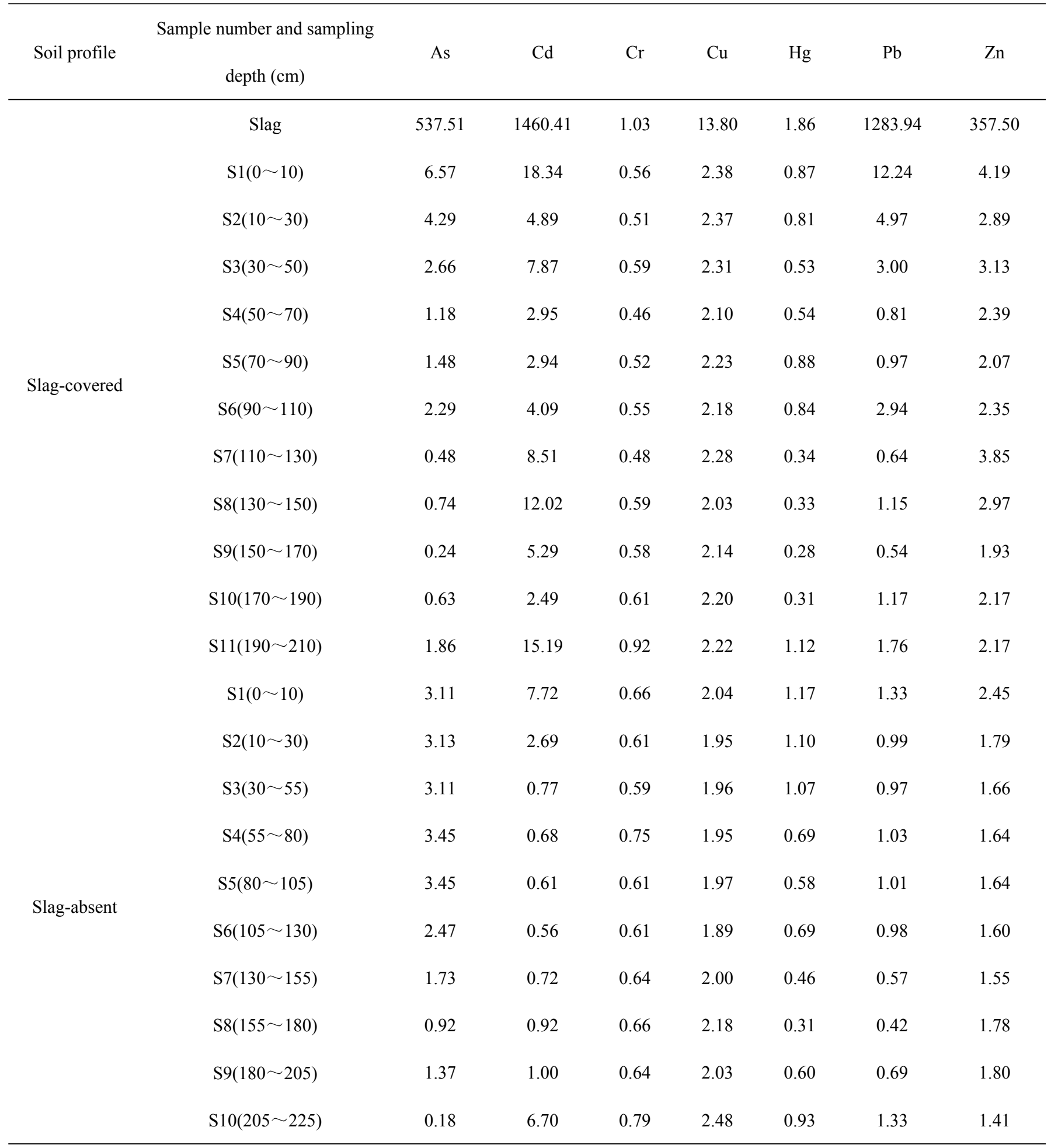


Figure 1

Potentially toxic metal(loid) distribution in both slag-covered and slag-absent weathering profile in the study area.

$A, B, C, D, E, F$, and $G$ respectively represent the content distribution of $\mathrm{As}, \mathrm{Cd}, \mathrm{Cr}, \mathrm{Cu}, \mathrm{Hg}$, $\mathrm{Pb}$, and $\mathrm{Zn}$ in the slag-covered weathering profile. And $\mathrm{H}, \mathrm{I}, \mathrm{J}, \mathrm{K}, \mathrm{L}, \mathrm{M}$, and $\mathrm{N}$ represent the concentration distribution of $\mathrm{As}, \mathrm{Cd}, \mathrm{Cr}, \mathrm{Cu}, \mathrm{Hg}, \mathrm{Pb}$, and $\mathrm{Zn}$ in the slag-absent weathering profile, respectively.
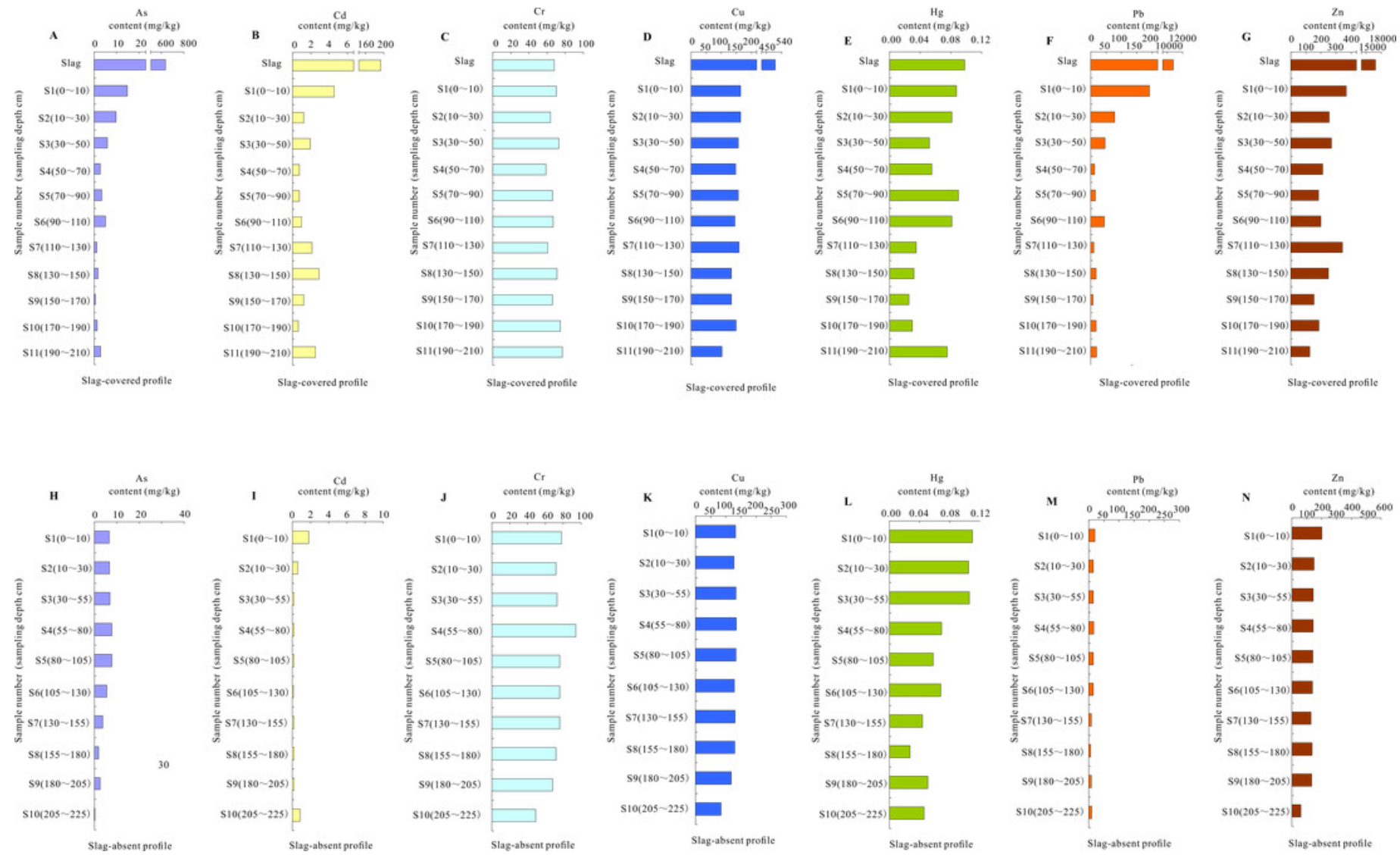
Figure 2

Transfer coefficients of potentially toxic metal(loid)s in both slag-covered and slagabsent weathering profile in the study area.

$\mathrm{A}, \mathrm{C}, \mathrm{E}, \mathrm{G}, \mathrm{I}$, and $\mathrm{K}$ respectively represent the transfer coefficient of $\mathrm{As}, \mathrm{Cd}, \mathrm{Cr}$ and $\mathrm{Cu}, \mathrm{Hg}, \mathrm{Pb}$, and $\mathrm{Zn}$ in the slag-covered weathering profile. And $B, D, F, H, J$, and $L$ respectively represent the transfer coefficient of $\mathrm{As}, \mathrm{Cd}, \mathrm{Cr}$ and $\mathrm{Cu}, \mathrm{Hg}, \mathrm{Pb}$, and $\mathrm{Zn}$ in the slag-absent weathering profile. 

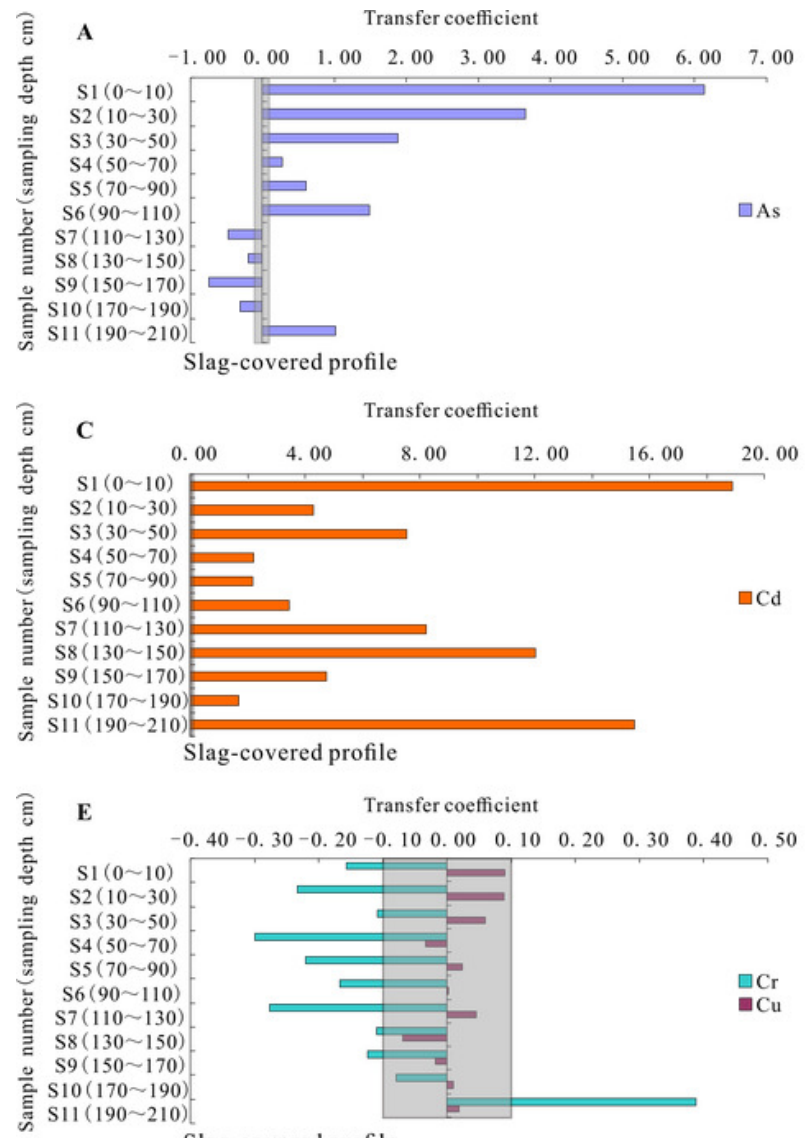

on Slag-covered profile

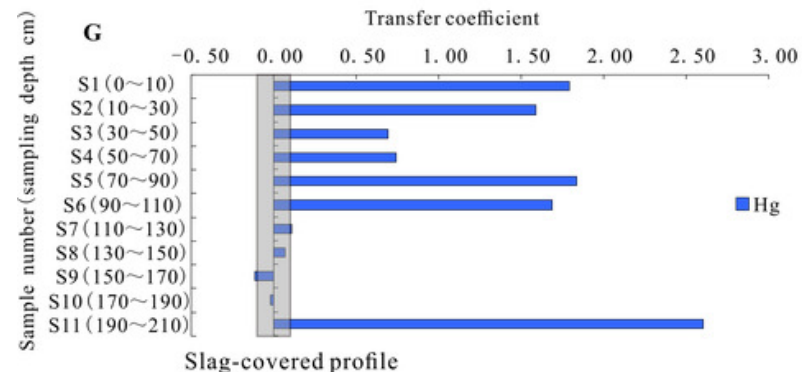

Slag-covered profile

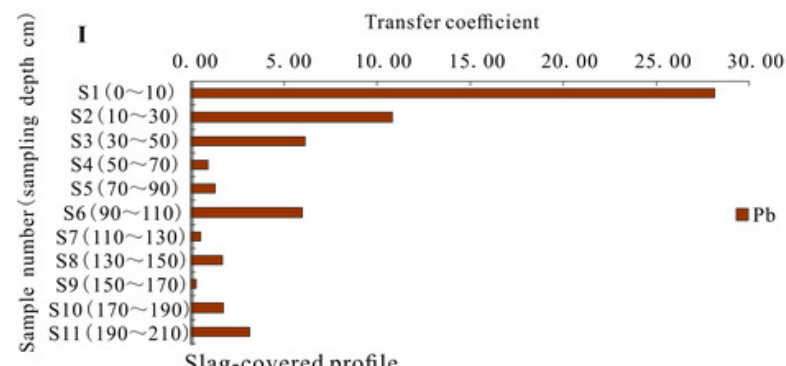

Slag-covered profile

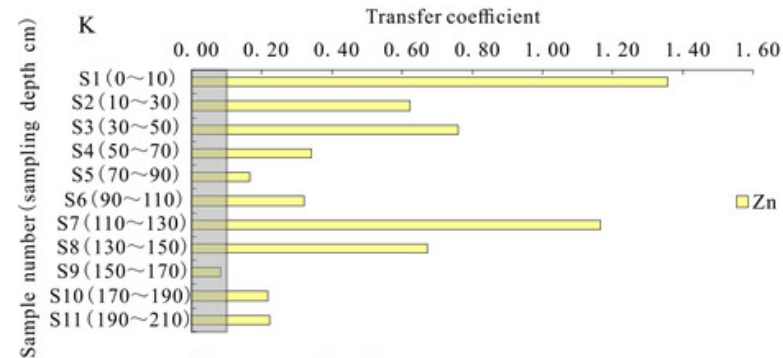

Slag-covered profile

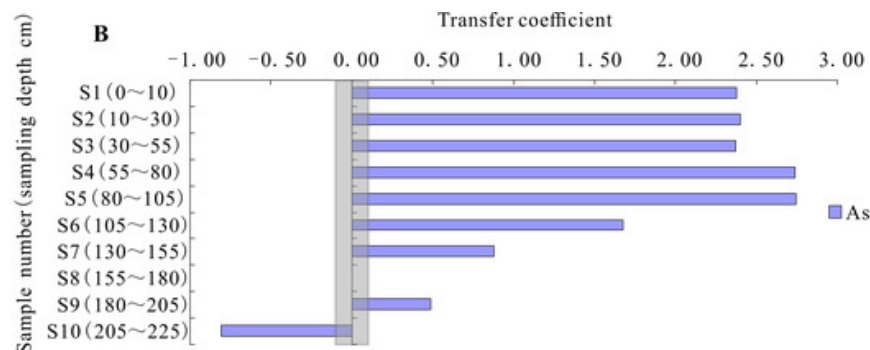

Slag-absent profile
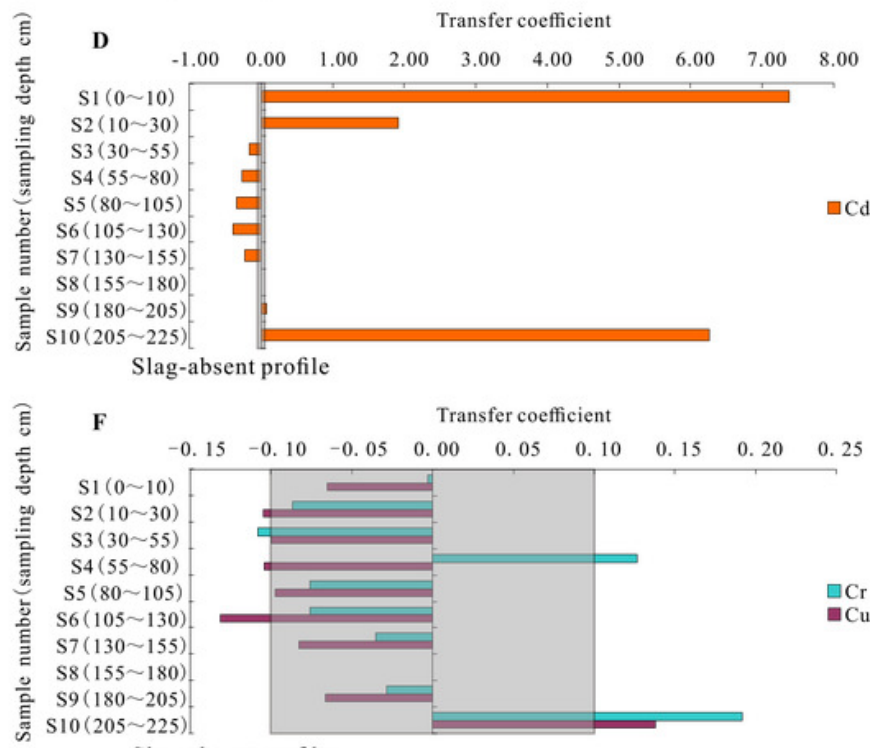

Slag-absent profile

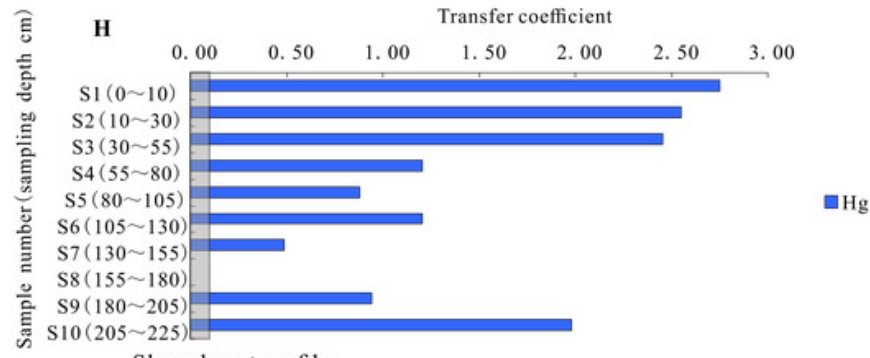

Slag-absent profile

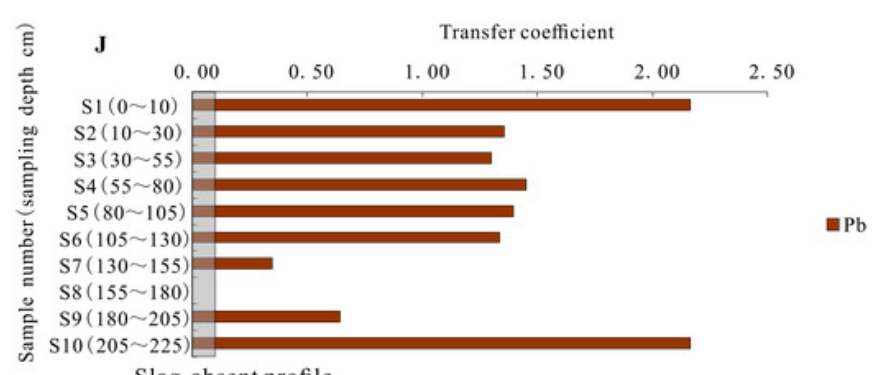

Slag-absent profile

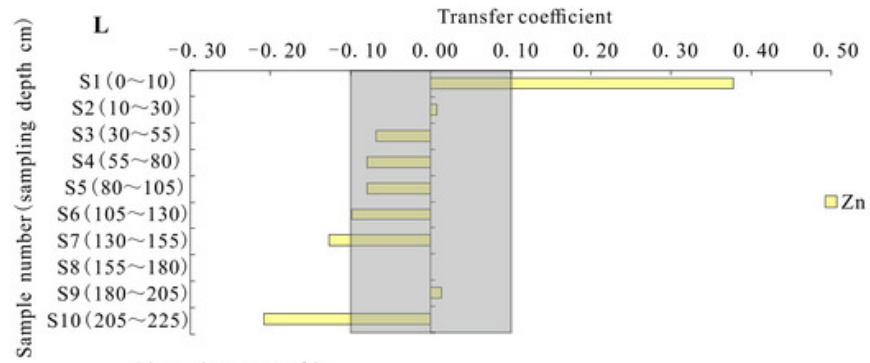

Slag-absent profile 